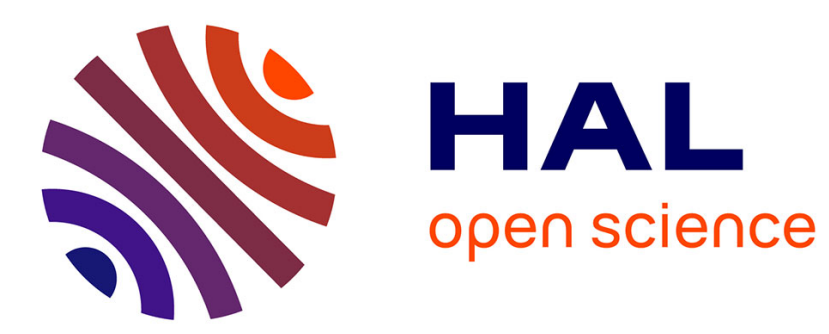

\title{
Financial Vulnerability in the Central and Eastern European Countries
}

\author{
Irène Andreou, Aleksandra Zdzienicka-Durand
}

\section{To cite this version:}

Irène Andreou, Aleksandra Zdzienicka-Durand. Financial Vulnerability in the Central and Eastern European Countries. 2009. halshs-00374148

\section{HAL Id: halshs-00374148 \\ https://shs.hal.science/halshs-00374148}

Submitted on 8 Apr 2009

HAL is a multi-disciplinary open access archive for the deposit and dissemination of scientific research documents, whether they are published or not. The documents may come from teaching and research institutions in France or abroad, or from public or private research centers.
L'archive ouverte pluridisciplinaire HAL, est destinée au dépôt et à la diffusion de documents scientifiques de niveau recherche, publiés ou non, émanant des établissements d'enseignement et de recherche français ou étrangers, des laboratoires publics ou privés. 
W.P. 09-07

\title{
Financial Vulnerability in the Central and Eastern European Countries
}

\author{
Irène Andreou, Aleksandra Zdzienicka
}

Avril 2009

GATE Groupe d'Analyse et de Théorie Économique

$$
\text { UMR } 5824 \text { du CNRS }
$$

93 chemin des Mouilles - 69130 Écully - France

B.P. 167 - 69131 Écully Cedex

Tél. +33 (0)4 72866060 - Fax +33 (0)4 72866090

Messagerie électronique gate@gate.cnrs.fr

Serveur Web : www.gate.cnrs.fr 


\title{
FINANCIAL VULNERABILITY IN THE CENTRAL AND EASTERN EUROPEAN COUNTRIES
}

\author{
Irène ANDREOU*, Aleksandra ZDZIENICKA*
}

First version: November, 2008

\begin{abstract}
In this work we use a panel probit model to analyze the sources of financial vulnerability in four Central and Eastern European countries. The incontestable advantages of applying this method, associated with some elements of the non-parametric approach applied during the initial selection of the used indicators, allow us to accomplish, rather well, this objective.

Indeed, the model performs considerably well in the sample and the whole approach can provide useful and supportive instruments for the study of financial vulnerabilities in transition economies.
\end{abstract}

JEL classification: C35 F31, F32

Keywords: Financial Vulnerability, Panel Probit Model, CEECs 


\section{Introduction}

After their EU adhesion, the Central and Eastern European countries (CEECs hereafter) prepare themselves to replace the national currencies with the euro, and even if this process brings incontestable benefits for each country, its costs and challenges cannot be ignored. Indeed, the most obvious price to pay for the common currency is the loss of independent monetary policy as a tool to deal with asymmetric shocks, increased capital inflows, and other financial turbulences. So, decisions on the timing of the euro adoption should be preceded by careful consideration of these risks and the substantial differences between the candidate countries and the common currency area (Schadler et al., 2005).

The CEECs have started their transition process almost 20 years ago and even if their economies show in many respects increasing similarities to developed economies, they still present some characteristics pointing to potential sources of increased financial vulnerability that have even increased in the recent period. The main objective of this paper is to study these vulnerabilities.

To do so, we focus on the four biggest CEECs, namely Hungary, Poland, and the Czech and Slovak Republics during the 1995-2006 period. The underling characteristics of these countries point to the several common features, especially when we compare them to other CEECs such as the Baltic countries. Moreover, these countries have been operating an independent monetary policy for most of the studied period (see Appendix C), and this implies greater changes in the macroeconomic framework that will be necessary during the euro adoption, than in the case of the other countries. So, even if country-specific characteristics are certainly well present, we can explore this first regularity and adopt a pooled approach, using the advantages of panel data (Baltagi, 2008).

To determine the potential sources of increased financial vulnerability, we apply the existing theoretical and empirical literature on financial crises. Indeed, there are few studies 
treating sources of financial vulnerability directly, but the aftermath of the financial crises since the end of the previous century has entailed an explosion of research in this last field. These works have allowed the identification of certain characteristics (vulnerabilities) of an economy that may make it prone to financial turbulence. Some of their contributions are also employed in our study. For example, we define an increased financial vulnerability situation using a variant of the market pressure index developed by Kaminsky et al. (1997), and to select indicators of financial vulnerability we adopt a two-step approach using the standard nonparametric signaling and non-linear (binary model) methods. However, despite many common features in our panel sample, we fear the presence of biasing country-specific effects and this is why we apply the panel probit model that takes these effects into consideration: a populationaverage model with a random-effects estimator.

The model constructed in this way has a good in-sample performance indentifying contagion, growing private sector indebtedness, short-term capital inflows, and interest and exchange rate volatility as the most significant indicators of increased financial vulnerability. So, even if the predictive power of this kind of method is known to be limited, the model may help determine particular features of the new EU countries and potential sources of financial weaknesses.

The rest of the paper is organized as follows. Section 2 briefly describes some underling characteristics of the CEECs that have played an important role in the recent period. Section 3 focuses on the existing research on financial turbulence. Section 4 concentrates on methodological issues. The estimation results are interpreted in Section 5. Section 6 concludes. 


\section{Characteristic features of CEECs' economies}

Like we mentioned before, the CEECs' economies started their transition to a market economy almost 20 years ago and today this process is nearly accomplished. The speed of transformation has been undoubtedly influenced by EU accession and convergence of the new economies to EU level. However, in most cases, the CEECs' real convergence, that is convergence of the level of income and structure of the economy to EU standards, progresses rather slowly. Indeed, the income gap measured by GDP per capita (at PPP) varies between 45 percent of the EU-15 average level in Poland, 57 percent in Slovakia and 60 percent in Hungary to 70 percent in the Czech Republic ${ }^{1}$. These figures corroborate the fact that the catching-up process in the CEECs is far from over.

Another characteristic feature concerns the financial sectors. The CEECs' financial markets remain underdeveloped and the financial sector is centered on the banking sector. Indeed, the average market capitalization accounts for about 30 per cent of GDP compared with 130 per cent in the euro zone and the domestic banking sector is growing rapidly. This last development has been clearly visible trough the rapid growth of bank credit to the private sector (Figure 1). Its level is far from that of the euro-zone, but the speed of the process has brought some fears about potential overheating and possible development of asset price bubbles. On the other hand, banks are dominated by international banking groups. Their shares in total banking assets vary from 70 percent in Poland, 80 percent in Hungary to almost 100 percent in the Czech and Slovak Republics. This brings us to another important characteristic: capital inflows.

\footnotetext{
${ }^{1}$ Raiffeisen Bank "CEE Banking Sector Report 2008"
} 
Figure 1: Main Economic Indicators
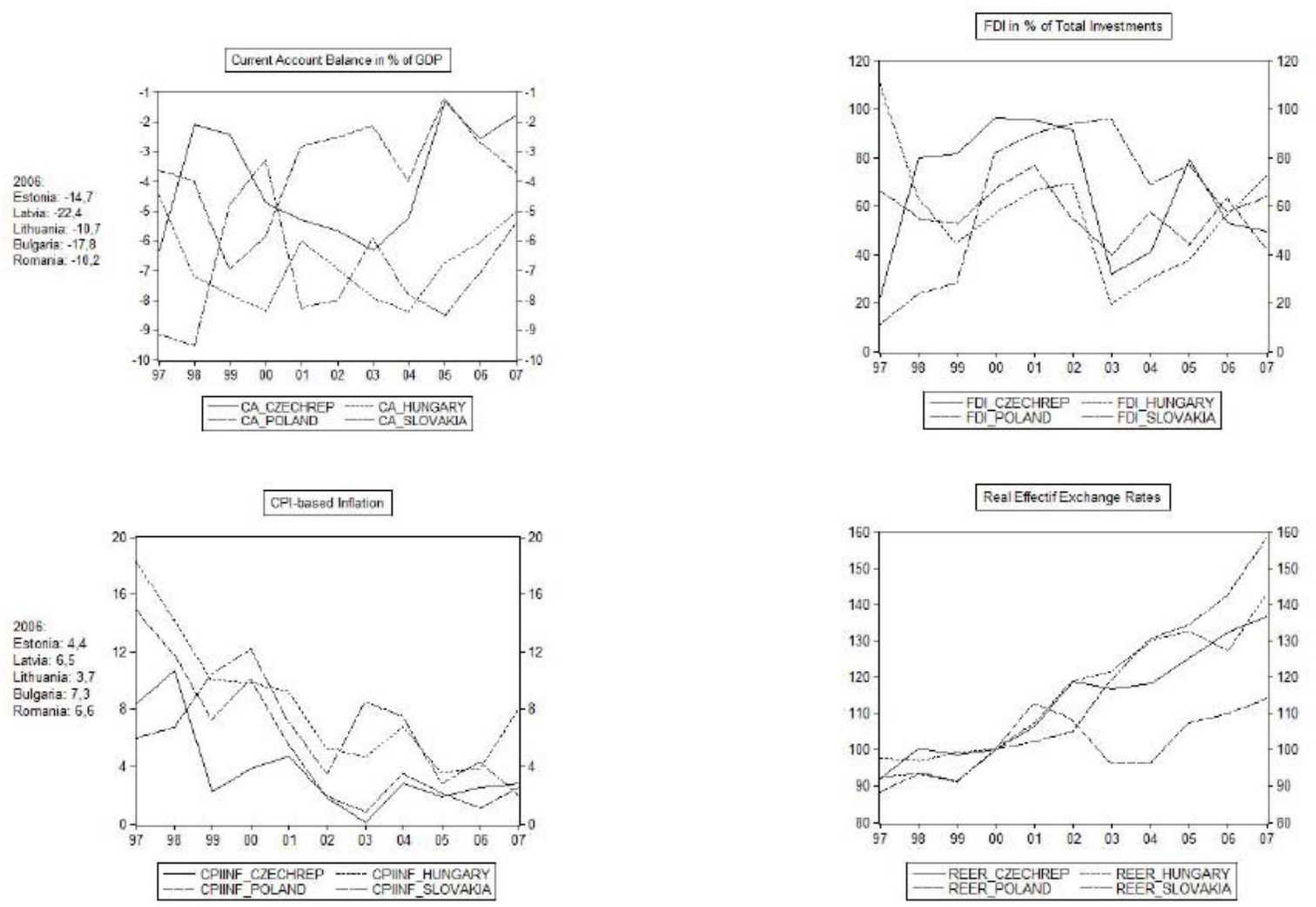

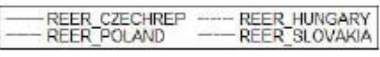
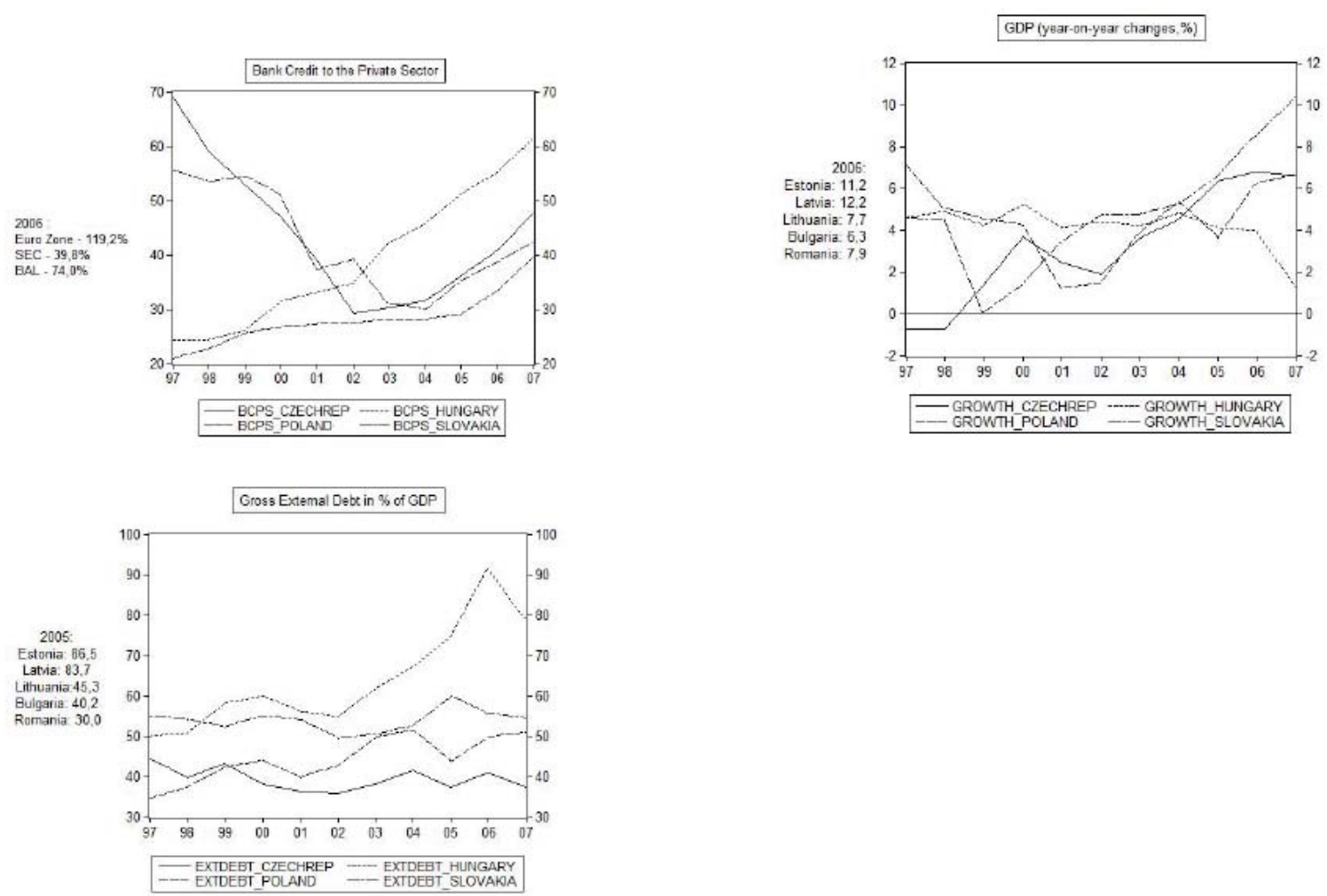

Source: IMF. IFS WEO. INSEE 
Capital flows into these economies are very large, volatile and, since the end of 1990 's, rather unrestricted. They have accounted in average for about seven per cent of GDP over the studied period and their volatility is rather high (the standard deviation of net annual flows over the 1995 - 2006 period varies between 60 and about 100 per cent). Capital inflows usually take the form of foreign direct investment (over 60 per cent of total inflows), but an increase of short-term capital inflows can also be noticed. Since the rate of return on investment is and will remain relatively high in the new countries due to the scarcity of physical capital, these capital inflows can persist during and after the euro adoption. This last tendency can also be reflected in the rather large current account disequilibrium. Indeed, the high rate of investment, especially compared to the level of saving, can explain the relatively large current account deficits concerning almost the entire region (Figure 1). Moreover, capital inflows contribute at least partly ${ }^{2}$ to the considerable real appreciation of the CEECs' currencies, but also their volatility can explain these countries' exchange rate fluctuations.

The last important feature mentioned here concerns the large fiscal deficit of all studied countries. For example in 2006, fiscal deficit reached 2.7\% of GDP in the Czech Republic, 3.6\% in Slovakia and Poland and $9.2 \%$ in Hungary. These deficits are mostly explained by the structural problems of the new countries, which will tend to increase with future demographic developments.

These aforementioned characteristics constitute potential sources of financial vulnerability not only during the period before the euro adoption, but also, as could be noted recently, in the context of global financial and economic turmoil. In the next section, we try to go into more detail concerning this problem, by providing a brief description of the general empirical literature on financial crises and of work on the CEECs' vulnerabilities as well.

\footnotetext{
2 Other factors explaining common real appreciation include the Balassa-Samuelson effect, the price and tax system transformation, or initial undervaluation (Schadler et al., 2005), but also recent loose monetary conditions and "excessive" credit growth (Christensen, 2008).
} 


\section{Research on financial turbulence}

The proliferation of financial crises at the end of the last century resulted in the explosion of empirical studies on the subject. Many authors put efforts in developing a warning system that may help in monitoring whether a country may be subject to a potential crisis. Their methods differ in many aspects from crisis definition, to analyzed countries, to the monitored variables chosen (i.e. indicators of financial vulnerability) to the period of study and data frequency. Generally, even if some analyses employ more than one methodology, we can distinguish three or four main groups of empirical work ${ }^{3}$.

The first group of studies, the most common, uses parametric methods in the form of non-linear models (probit, logit). The binary dependent variable relates the probability of a crisis to a set of explanatory variables. The incontestable advantage of this method is the possibility to incorporate correlation among variables (which do not need to be dichotomous) and the possibility to use the standard statistical tests. These discrete choice models determining the causes of crises, allow us to assess indirectly the probability of their occurrence, but do not permit us to test the probability of their timing ${ }^{4}$.

The second group of non-parametric methods uses a large set of variables to indicate the vulnerability to crises. The authors applying this method suppose that the particular behavior of some indicators may be useful in crisis prediction. Indeed, a warning signal of potential financial turbulence is sent when the crisis index and vulnerability indicators exceed some threshold values. This method has good in-sample effectiveness, but fails in out-sample predictions of crises $^{5}$.

\footnotetext{
${ }^{3}$ Our classification is principally based on the ones by Collins (2003) and Abiad, (2003).

4 The method was initiated by Eichengreen et al. in 1996, used by Frankel and Rose in 1996, Berg and Patillo in 1998, but also by many others such as Schardax in 2002, and Collins in 2003. Some authors preferred the logit specification (Bussière and Fratzscher in 2002).

5 This approach was initiated by Eichengreen, Rose and Wyplosz in 1995, popularized by Kaminsky and Reinhart in 1996, and developed by Kaminsky et al. in 1997 and Goldstein et al. in 2000. The signaling method was also applied
} 
A third group of methods (detailed in Kaminsky et al., 1997, and subsequently) includes a qualitative discussion without formal tests and stylized facts about the period leading up to and directly following crisis periods. Moreover, some parametric and non-parametric tests are used to determine the difference between crises and periods of tranquility.

The last group of empirical works includes such methods as the Markov regime switching model, artificial neutral network (ANN) analysis, value at risk (VaR) models, or Fisher discriminant analysis. These methods try to address the main limitation of the standard approaches, namely the fact that future crisis prediction is based on crisis history itself, i.e. $e x$ post chosen indicators, the market pressure index, etc.

On the other hand, the literature on financial vulnerabilities in CEECs has been growing rapidly since the first decade of their transition process, but the perspective of the EMU enlargement gave even more impetus to their development.

Work in this field is very heterogeneous. Some authors proceed to overall analysis of potential vulnerabilities using a qualitative method, describing the stylized facts of the studied economies (Backé and Wojcik, 2003), regrouping existing analytical and empirical works to draw conclusions (Schadler et al., 2005). Certain studies concentrate on vulnerability analysis from a particular point of view such as a balance sheet approach (Menegatti and Roubini, 2006) or external sustainability (Lane and Milesi-Ferretti, 2007). A common way of tackling the financial vulnerability problems is to treat them one by one. Indeed, empirical studies analyze separately the probability of current account volatility or exchange rate volatility, credit booms or foreign capital flow reversals.

To our knowledge, there are only few empirical studies (Krkoska, 2000, Schardax, 2002) treating vulnerability to financial crises in transition countries using traditional approaches. Usually some CEECs are included in more general analyses on developing countries (Kaminsky et al., 1997; Edison, 2000). The reasons for this are obvious: limited availability and reliability Dufrénot, Sand-Zantman and Zdzienicka in 2007.\}. 
of the data, a small number of crisis episodes, rather weak statistical significance of the models, etc. Therefore, these approaches focusing on a very heterogonous group of countries do not allow for the confirmation of the relevance of the theoretical assumptions and the selected indicators of vulnerability.

In our work, like we mentioned before, we try nevertheless to analyze the CEECs' financial vulnerabilities within the traditional framework. So, in order to analyze the sources of an increased financial vulnerability in the case of the studied countries, we try to associate the two most popular methods: the standard non-parametric signaling method and the non-linear method (binary panel model). However, before doing this we must first define the situation of an increased financial vulnerability and its potential indicators.

\section{Methodology}

\subsection{Defining financial vulnerability}

It is rather difficult to clearly define what a situation of increased financial vulnerability actually is. One can describe it as a situation that can lead an economy into financial crisis, but in this case we still face the problem of the definition of the financial crisis itself. However, since this aspect has been largely discussed in the literature, we can rely on previous works for both assessments.

Indeed, financial vulnerability can manifest itself in several ways, such as severe pressure on the domestic currency with high costs on the external balance, banking system and/or debt problems. This is why we decide to adopt a similar criterion for the definition of an increased financial vulnerability as that used for a crisis definition. We construct the index, similar to the commonly used market pressure index that can be defined as follows:

$$
I N D_{i}=\sigma_{1 i} \delta R E E R_{t}-\sigma_{2 i} \delta R E S E R V E S_{t}
$$


where, $\delta R E E R_{t}$ stands for the real effective exchange rate variation and $\delta R E S E R V E S_{t}$ for the variation in the domestic foreign exchange reserves. $\sigma_{1 i}$ and $\sigma_{2 i}$ indicate the volatility of the changes occurring in the real exchange rate and foreign reserves, which are measured by the standard deviation of these two variables.

We use the real rather than nominal exchange rate to obtain a more realistic view of turbulence episodes in transition countries, since during the period under analysis these countries have adopted various exchange rate regimes. Moreover, to avoid the risk that an increased financial vulnerability situation can be misidentified, we include the domestic foreign exchange reserves variation.

Finally, we can say that an increased financial vulnerability (IFV) situation occurs when pressures in the exchange rate market and domestic foreign exchange reserves losses are considerable, i.e. they exceed a certain threshold value $c$.

This situation can be described using the following definition:

$$
I F V= \begin{cases}1, & \text { if } I N D \geq c \\ 0, & \text { otherwise }\end{cases}
$$

The threshold value can be defined as:

$$
c=\bar{x}_{I N D}+\delta \sigma_{I N D}
$$

Where $\bar{x}_{I N D}$ is the empirical mean of the financial vulnerability index and $\delta \sigma_{I N D}$ is its standard deviation. We set the value of $\delta$ at 0.75 . In the case of financial crises this value usually varies between 1.5 and 3 (Edison, 2000), but as we stressed before, the situation of increased financial vulnerability can precede crisis onset, and it is this situation that we seek to pinpoint. 
This value presents another incontestable advantage: the country can face a situation of increased vulnerability without actually going into a financial crisis and the index thus defined is still able to detect it.

\subsection{Indicators of financial vulnerability}

On the basis of the existing theoretical works ${ }^{6}$ and empirical research on financial crises, as well as empirical analyses of the transition economies, we can distinguish several potential sources of financial vulnerability (Table 1). Indeed, most of these countries show (i) large macroeconomic disequilibria. The need for new financing to cover the still considerable fiscal ${ }^{7}$ and widening current account deficits, but also the increasing potential cost of this financing can be considered as the most probable source of financial vulnerability in transition countries. Moreover, the way that these (ii) deficits are financed, i.e. by issuing short - term foreign-denominated debt rather than long term bonds, equities, or foreign direct investment, may also constitute an additional source of vulnerability.

In the case of crises or adverse shocks, a country can face the problem of raising the new funds and honoring existing debts, especially when the easier way to deal with external imbalances - domestic currency depreciation - increases the foreign-denominated debt burden. Finally, past and ongoing current and fiscal deficits can lead to doubts about the authorities' ability to reduce the unsustainable accumulation of debt (Roubini, 2001). Indeed, intertemporal solvency requires that the country's internal and external debt must be stable and its increase over time can lead to a debt, and currency and general financial crises (Reinhart, 2002).

Some potential sources of financial vulnerability can also be found at the (iii) financial sector level. In the CEECs, especially in the new EU countries, such distortions as poor

\footnotetext{
6 Traditionally, academic research on financial crisis and their causes can be described on the basis of three generation models

${ }^{7}$ We exclude this indicator from the analysis due to data availability problems.
} 
regulation or government guarantees are usually irrelevant, but others, like credit booms, can increase financial instability. Indeed, growth in permanent income, large investment opportunities and the perspective of the euro adoption will attract foreign capital inflows and lead to rapid bank credit growth to the private sector (Enoch and Ötker-Robe (editors), 2007). On the other hand, the credit boom may entail banking sector illiquidity and insolvency problems, an overheating of the economy or asset price bubbles. Increased capital inflows can also lead to excessive and destabilizing (from an economic point of view) volatility in interest and exchange rates (Aizenman and Riera-Crichton, 2006). Moreover, dealing with the abovementioned issues without a fully independent and credible monetary policy would constitute an additional source of vulnerability. Indeed, recent financial crisis history shows that (iv) fixed and "heavily managed" exchange rates have doubtlessly contributed to their onset (Bubula and Ötker-Robe, 2003). In the case of the studied transition countries, the euro adoption process, especially the necessity to peg their exchange rates to the euro during at least two years within the limits of the ERM II arrangement, may increase underling existing economic and financial vulnerabilities, such as capital account volatility.

Still, some other important sources of vulnerability, (v) external shocks, stay outside of these countries' control, especially in the era of financial liberalization. Prior to the ERM II period, authorities dispose of some limited tools to deal with such shocks. However, some phenomena, such as contagion, usually stay beyond the authorities' direct control in any case. 
Table 1: Financial Vulnerability Indicators with the corresponding Noise-To-Signal (NTS) ratio.

\begin{tabular}{|c|c|}
\hline INDICATOR & NTS \\
\hline \multicolumn{2}{|l|}{ Macroeconomic disequilibria } \\
\hline Commercial Balance/GDP & 1.388 \\
\hline Current Account/GDP & 0.918 \\
\hline External Debt/GDP & 1.600 \\
\hline \multicolumn{2}{|l|}{ Deficit Financing } \\
\hline Equity/Debt Ratio & 0.377 \\
\hline FDI/GDP & 1.012 \\
\hline Short-term Capital Inflows & 0,400 \\
\hline \multicolumn{2}{|l|}{ Financial Sectors Vulnerabilities } \\
\hline Domestic Credit/GDP & 1,718 \\
\hline Banking Credit to Private Sector & 1.435 \\
\hline Foreign Liabilities in Banking Sector & 1.529 \\
\hline Commercial Bank Deposits & 0.756 \\
\hline \multicolumn{2}{|l|}{ Exchange Rate } \\
\hline Real Exchange Rate Appreciation & 0.3765 \\
\hline Exchange Rate Deviation from Linear Trend & 1.341 \\
\hline Exchange Rate Volatility & 0.635 \\
\hline \multicolumn{2}{|l|}{ Others* } \\
\hline Growth & 0,424 \\
\hline Financial Liberalization & 0,424 \\
\hline Financial Account Volatility & 1.054 \\
\hline Inflation & 1.03 \\
\hline Interest Rate Volatility & 0.675 \\
\hline $\mathrm{M} 2 / \mathrm{GDP}$ & 1.529 \\
\hline \multicolumn{2}{|l|}{ External Shocks/Contagion } \\
\hline Emerging Markets Financial Situation & 0.400 \\
\hline Russian Crisis & 0.2118 \\
\hline
\end{tabular}

*Indicators fall in more than one category

Source: Authors' calculations 
After this preliminary analysis of potential sources of financial vulnerability and in order to construct a robust system detecting financial vulnerability in transition economies we apply two different approaches.

First we identify the variables ${ }^{8}$ with the best predictive power using the signaling method, and then we include them in a binomial probit model. By doing this we check the validity of the functional specification (i.e. significant variables with the expected signs) between the chosen variables and the dependent variable of increasing financial vulnerability in the countries under consideration ${ }^{9}$.

\subsection{Selecting the best - performing indicators: the signaling approach}

The non-parametric signaling approach used to select the best-performing indicators is based on the assumption that some variables' behavior is different before the financial crisis and during the tranquil period. In practice, this procedure necessitates the determination of a threshold value that, when crossed, will indicate a change in the prior-to-crisis-variable behavior. This threshold value should not be set too high or too low. The first case would result in too many missed signals while the second could result in an excessively high number of wrong signals. The most common way to determine this optimal threshold value is to select the one that minimizes the noise-to-signal ratio.

To calculate the noise-to-signal ratio (see Appendix A for more details), we assume that a variable signals a crisis situation if it exceeds some threshold value before the crisis actually occurs (our "crisis window" is set at four quarters before the onset of the financial turbulence).

\footnotetext{
8 We use quarterly data for the period 1995-2006 provided by the IMF International Financial Statistics, National Statistics Offices and the EMBI data on http://www.mecon.gov.ar/peconomica/basehome/infoeco.html.

For a more detailed description, refer to Appendix B.

9 For a more detailed description see Krznar (2004), to which this stage of our work is the closest from a methodological point of view. The author, applying some elements of the signaling approach and running the probit model estimations, obtains a high level of predictive power in the sample.
} 
Given this, four situations can occur: the variable signals a crisis and the crisis takes place $(A)$ or not $(B)$, and the variable does not signal the crisis, but this one occurs $(C)$ or not $(D)$. The noise-to-signal ratio is the ratio of bad signals to good ones:

$$
N T S=\frac{B /(B+D)}{A /(A+C)}
$$

Table 1 above associates the previously selected variables to their noise-to-signal ratios. Usually, only the variables for which the noise-to-signal ratio does not exceed one are selected as the best indicators of financial turbulence. Therefore, in our case, the selected variables perform relatively well, and that's why we try to choose only those variables for which the noise-to signal ratio is well inferior to one as potential indicators of financial vulnerability.

\subsection{The Probit Model}

Before the detailed presentation of the probit model three remarks need to be made.

- Since the financial vulnerability of an economy increases with the number of indicators signaling it, the best-performing indicators can be regrouped in a composite indicator. This indicator, besides its information role, allows us to indirectly measure the conditional probability of increasing financial vulnerability. This method performs well when the signaling variables, transformed into a step function, show a clear differentiated behavior prior to a crisis and under normal conditions, but otherwise obviously entails information losses.

- This and another limit of the signaling approach can be addressed by applying the binary method. Moreover, it is a plausible assumption that the relationship between the independent variables and the dependent one cannot be effectively explained by the step function, but can alternatively be assessed using a binary non-linear model 
(see Berg and Pattillo, 1999). However, the introduction of a large number of independent variables in the model increases the probability of linear dependence between individual independent variables. The consequence is that we can meet difficulties in inverting the matrix of independent variables (i.e. a near-singular matrix), to evaluate the model parameters. So, in the case of a large number of wellperforming indicators, such as ours, some preliminary selection of the variables is still necessary. As mentioned before, the signaling method is used for this purpose. Then, the relationship between the pre-selected indicators and the dependent variable is examined by applying the probit model.

- However, the presence of individual effects in the panel data makes the use of the standard probit model more complicated. Indeed, since the number of error term parameters increases with the number of countries, it cannot be consistently estimated for a fixed time period ${ }^{10}$. In this case, a popular solution has been the use of the panel probit model and the random-effects estimator.

The panel probit model can be described by the following equation:

$$
y_{i t}^{i}=x_{i t}^{l} \beta+u_{i t}
$$

where $y_{i t}^{*}$ is a latent variable, but we can observe the binary variable, which is equal to 1 if $y_{i t}$ is superior to 0 , i.e. the event happens for country $i$ at time $t$, and is equal to 0 otherwise.

We can decompose the error term into two components $u_{i t}=\alpha_{i}+\mu_{t}$, where $\mu_{t} \sim$ i.i.d. $N\left(0, \delta_{\mu}^{2}\right)$ and $\alpha_{t} \sim$ i.i.d. Both are independent of each other and of the $x_{i t}{ }^{11}$.

\footnotetext{
10 See Baltagi (2008) for a more detailed explanation of the incidental parameters problem.

11 Since $E\left(\mu_{i z}, \mu_{i s}\right)=z_{\mu}^{z}$ for $t \neq s$, the realizations of $y_{i \mathrm{t}}$ for each $i$ are correlated, which complicates the derivation of maximum likelihood involving T-dimensional integrals. However, to achieve this, Butler and Moffitt (1982) suggested the use of the Gaussian-Hermite quadrature procedure.
} 
To measure the effects of the increased financial vulnerability indicators on its actual occurrence, we estimate a population-average model. This specification models the marginal expectation of the dependant variables across the population, i.e. averages it across random effects. The estimation results are then tested for the expected sign and the statistical significance of the coefficients in the equation, and the insignificant variables with unexpected signs are eliminated. Finally, we analyze the estimation results of the final specifications and test their performance, i.e. the goodness-of-fit of the model.

\subsection{Assessing the model's performance}

One way of testing the model's performance is via the Likelihood Ratio (LR), which is distributed as a $\chi^{2}$ statistic with k-1 degrees of freedom, where k-1 is the number of independent variables in the model, under the null hypothesis that the coefficients of the variables are all jointly equal to zero. The way to test for LR significance is provided by the "Probability (LR stat)" values. These measures show the general statistical significance of the models at the $1 \%$ level.

We can test the models for their predictive power in the sample. The most commonly used method consists in comparing the predicted probabilities of increased financial vulnerability periods with their actual occurrence. To calculate the percentage of outcomes correctly predicted, we take the prediction in observation $i$ as 1 if $p_{i}$ is grater then 0.5 , which is our probability threshold, and 0 if it is less. In general, when this goodness-of-fit measure is considered, our models perform considerably well in the sample. 
Table 2: Probit Model Estimation: the final model

\begin{tabular}{|c|c||c|}
\hline VARIABLE & CoEFFICIENT & Z-STATISITCS \\
\hline Short-Term Capital Inflows & 0,0002 & $1.45^{* * *}$ \\
Interest Rate Volatility & 0,0355 & $1.99^{* *}$ \\
Commercial Banks Deposits & -0.0003 & $-1.66^{*}$ \\
Exchange Rate Volatility & 0,0391 & $2.20^{*}$ \\
Equity-Debt Ratio & $-0,0999$ & $-2.91^{*}$ \\
Growth & $-0,0026$ & $-2.33^{* *}$ \\
Emerging Markets Financial Situation & $-0,0011$ & $-5.86^{*}$ \\
Russian Crisis & 0,4173 & $2.13^{* *}$ \\
\hline \hline Probability (LR stat) & 0.000 & \\
\hline$\%$ of correctly prediceted events & $83 \%$ & \\
\hline \hline
\end{tabular}

$* / * * / * * *$ signifiant respectively at the $1 \%, 5 \% 10 \%$ level

Source: Authors' estimations

However, despite the rather good performance in assessing the determinants of financial vulnerability, the model provides only a general direction of the influence of each variable on the increase in financial vulnerability. Indeed, like we mentioned before, the probit model is non-linear, so in order to interpret the estimated coefficients of the independent variables as their marginal contributions to the dependent variable probability, we should assume a certain value for the explanatory variables.

The most common way to do this is to evaluate these marginal effects at the mean of each significant variable according to the following formula:

$$
\frac{\delta P}{\delta x_{i}}=\beta_{i} \theta(Z)
$$


where $\theta$ is the density function of a standard normal distribution.

Table 3 reports the effect of these quantity changes in the independent variables on the predicted probability of increased financial vulnerability.

Table 3: Marginal Impact of Variables on Financial Vulnerability Increase

\begin{tabular}{|c|c|}
\hline Variable & Marginal Effect AT Mean \\
\hline Short-Term Capital Inflows & 0,0001 \\
Interest Rate Volatility & 0,0079 \\
Commercial Banks Deposits & -0.0001 \\
Exchange Rate Volatility & 0,0087 \\
Equity - Debt Ratio & $-0,0222$ \\
Growth & $-0,0001$ \\
Emerging Markets Financial Situation & $-0,0002$ \\
Russian Crisis & 0,1566 \\
\hline
\end{tabular}

Source: Authors' calculations

The figures in the table should be interpreted as follows: a one percent increase in shortterm capital inflows from their mean increases the probability of the occurrence of increased financial vulnerability by $0.1 \%$.

\section{Interpreting the estimation findings}

The situation of increased financial vulnerability in the CEECs, over the 1995-2006 period, was strongly connected to the Russian financial turbulence, which advocates in favor of strong spillover effects through the financial links between the two zones. This argument can be confirmed by the performance of the EMBI indicator in financial vulnerability prediction, which is rather good. This seems to underline the impact of contagious financial turbulence in all emerging markets. An important economic indicator of increasing financial vulnerability 
can also be found in the growing private sector indebtedness, given by the equity-to-debt ratio. However, we are rather cautious about the predictive power of this indicator, since it can be biased by the size of the equity market, which remains considerably smaller compared to the bond one. The next two indicators, real appreciation and short-term capital inflows are rather standard signals of growing financial problems, but while the role of short-term capital inflows is confirmed by our parametric model, real appreciation appears to be insignificant. On the other hand, we find a significant functional relation between exchange rate volatility, measured by the so-called "z-score" (Ghosh et al., 2002), and increasing financial vulnerability. The last two findings can be explained by the fact that while real appreciation can be seen as a "continuous process", due to higher productivity growth in the tradable sector or investors' optimism concerning the CEECs' economic performance, exchange rate volatility can indicate just the opposite. Indeed, it can be explained by its sensitivity to economic shocks, such as terms of trade shocks, capital inflows or other external turbulence (Aizenman and RieraCrichton, 2006). Here, it seems worth stressing that growth deceleration also contributes to an increase in financial vulnerability. Moreover, the CEECs' experience confirms rather common findings: the fact that interest rate volatility is undoubtedly a good sign of financial vulnerability in emerging markets (Edwards, 1998). It also confirms the fact that financial turbulence is usually a consequence of the financial liberalization process, or that financial vulnerability can be signaled by a decrease in commercial bank deposits.

The impact of other indicators on increasing financial vulnerability seems to be less important or even insignificant. In the case of some variables, such as the current account deficit, this can be explained by the fact that they are financed, for the most part, by foreign direct investment that counts, like we mentioned before, for 60 percent of total capital inflows (on average). On the other hand, the weak performance of domestic-credit-related variables, such as bank credit to the private sector, can be attributed to the fact that the so-called "credit boom" is a rather recent development and has not contributed to the increase in financial 
vulnerability as captured by our model. The relatively weak performance of the bank foreign liabilities indicator can be surprising, since the CEECs' banking sector is dominated by international groups. The reasons for this can be found in the strong predominance of domestic sources in credit financing over the studied period.

Generally speaking, we can stress the fact that sources of financial vulnerability change over time with countries' economic development and challenges ahead. In this way, the impact of variables such as inflation or external indebtedness has weakened due to their more stable trend in most of the CEEC economies. On the other hand, the importance of variables like domestic credit growth (Cottarelli et al., 2003), current account deficit or capital account volatility (Schadler et al., 2005) can be considered as the most important potential sources of vulnerability for the present and the future.

\section{Conclusion}

In this work we used the non-linear binary panel model to determine the sources of financial vulnerability in four Central and Eastern European countries. The incontestable advantages of applying this method, especially in the case of the relatively short data span for the CEECs' economies, associated with some elements of the non-parametric approach used during the initial selection of indicators, allow us to accomplish this objective.

Our work is obviously based on an empirical analysis, using standard research approaches to treat the complicated problems of financial crises. Like other studies in the field, this method has good in-sample performance, but should not be used to predict financial turbulence. Indeed, methods based on previous experiences to select crisis indicators have rather weak predictive power, measured by out-of-sample performance of the models, when anticipating future financial turbulence. 
Despite these limitations, the approach provides useful and supportive instruments for the study of financial vulnerability in transition economies. This is especially true when looking at the recent situation in most CEECs. Some indicators of financial vulnerability, as developed in previous studies and put forward in this work, have signaled a visible deterioration of their financial and economic situation. However, this development did not draw enough attention either from academic economists or financial markets until at least the third quarter of 2008 , when a visible worsening of the global financial situation made everyone more attentive to the potential crisis-driving signs in transition economies. 


\section{REFERENCES}

Abiad A., 2003, "Early-Warning Systems: A Survey and a Regime-Switching Approach", IMF Working Paper WP/03/32.

Allen M., Ch. Rosenberg, Ch. Keller , B. Setser and N. Roubini, 2002, "A Balance Sheet Approach to Financial Crisis”, IMF Working Paper WP/02/210

Andreou I., G. Dufrénot, A. Sand-Zantman and A., Zdzienicka A., 2007, "A Forewarning Indicator System for Financial Crises: the case of six Central and Eastern European Countries", Journal of Economic Integration (forthcoming).

Aizenman J., D. Riera-Crichton , 2006, "Real Exchange Rate and International Reserves in the Era of Growing Financial and Trade Integration”, NBER Working Paper no. 12363.

Baltagi B.H., 2008, "Econometric Analysis of Panel Data”, John Wiley and Sons Ltd. Editions.

Backé P. and C. Wojcik, 2003, "Alternative Options for the Monetary Integration of Central and Eastern European EU Accession Countries", Occasional Paper No. 3/2002, University of Ljubljana, Institute of Economic Research.

Berg A., E. Borenstein and C. Patillo, 2005, "Assessing Early Warning Systems: How Have They Worked in Practice?", IMF Staff Paper, Vol. 52, Number 3.

Berg A. and C. Pattillo, 1999, "Predicting Currency Crises: The Indicators Approach and an Alternative”, IMF Staff Paper, Palgrave Macmillan Journals, vol. 46(2).

Brüggemann A. and T. Linne, 2002, "Are the Central and Eastern European Transition Countries Still Vulnerable to a Financial Crisis?: Results from the Signals Approach”, Bank of Finland Institute for Economies in Transition, BOFIT Discussion Paper.

Bussière M. and M. Fratzscher, 2002, "Towards a New Early Warning System of Financial Crises”, ECB Working Paper, number 145. 
Bubula A. and I.Ötker-Robe, 2003, "Are Pegged and Intermediate Regimes More Crisis Prone?", IMF Working Paper WP/03/223.

Collins S., 2003, "Probabilities, Probits and the Timing of Currency Crises", Georgetown University, The Brookings Institution and NBER.

Cottarelli C., G. Dell'Ariccia and I. Vladkova-Hollar, 2003, "Early Birds, Late Risers, and Sleeping Beauties: Bank Credit Growth to the Private Sector in Central and Eastern Europe and the Balknas", IMF Working Paper WP/03/213.

Christensen L., 2008, "Unwinding New Europe imbalances-How bad will be it?" www.euro50.org/2008/budapest/Christensen.doc.

Edison H., 2000, "Do Indicators of Financial Crises Work? An Evaluation of an Early Warning System", Federal Reserves Board of Governors, International Finance Discussion Papers, Number 675.

Edward S., 1998, "Interest Rate Volatility, Capital Controls and Contagion", NBER Working Paper no 6756.

Eichengreen B., A. Rose and Ch. Wyplosz, 1996, "Contagion Currency Crises: First Tests", Scandinavian Journal of Economics, vol. 98(4).

Enoch Ch. And I. Ötker-Robe (dir.), 2007, "Rapid Credit Growth in Central and Eastern Europe: Endless Boom or Early Warning?”, Palgrave Macmillan eds., 2007.

Ghosh A.R., A.-M., Gulde and H.C. Wolf, 2002, "Exchange Rate Regimes. Choices and Consequences", Business \& Economics.

Goldstein M., G.L. Kaminsky and C.M. Reinhart C.M., 2000, “Assessing Financial Vulnerability: An Early Warning System for Emerging Markets", Washington: Institute for International Economics. 
IMF Country Report No.07/250

IMF Country Report No.08/39

IMF Country Report No.08/130

Kaminsky G.L., S. Lizondo and C.M. Reinhart, 1997, "Leading indicators of currency crises", Policy Research Working Paper Series 1852, The World Bank.

Kiss G., M. Nagy and B. Vonnak, 2006, "Credit Growth in Central and Eastern Europe: Trend, Cycle or Boom”, MNB Working Paper 2006/10.

Krkoska, L., 2000, “Assessing Macroeconomic Vulnerability in Central Europe”, European Bank for Reconstruction and Development, Working Paper No. 52.

Krznar I., 2004, "Currency Crisis: Theory and Practice with Application to Croatia", CNB Working Paper, W-12.

Lane Ph.R. and G.M. Milesi-Ferretti, 2006, "Capital Flows to Central and Eastern Europe", IMF Working Paper no.06/188.

Menegatti, C. and N. Roubini, (2006), "Vulnerability in Central and Southern Europe", www.rgcmonitor.com.

Martinez-Peria M., 2002, “A Regime Switching Approach to Studying Speculative Attacks: A Focus on EMS Crises", Empirical Economics 27(2).

Natixis, 2008, “Europe centrale et Orientale”, novembre 2008

Natixis, 2009, "Europe centrale et Orientale", janvier 2009

Raiffeisen Bank Research, 2008, “CEE Banking Sector Report 2008", www.raiffeisenbank.ba/en/vijesti/2008/02102008.htm.

Reinhart C.M., 2002, "Sovereign Credit Ratings Before and After Financial Crises", MPRA Paper 7410, University Library of Munich, Germany. 
Roubini N., 2001, "Lessons Learnt from Crises in Emerging Economies”, www.rgcmonitor.com.

Schadler, S., P. Drummond, L. Kuijs, Z. Murgasova and R. van Elkan, 2005, "Adopting the Euro in Central Europe: Challenges of the next Step in European Integration”, IMF Occasional Paper, 234.

Schardax F., 2002, "An Early Warning Model for Currency Crises in Central and Eastern Europe”, Foreign Research Division, OeNB.

Schinasi G., 2005, "Safeguarding Financial Stability: Theory and Practice", IMF Publication. 


\section{APPENDIX A}

\section{Calculating the noise-to-signal ratio}

Consider the following situations ${ }^{12}$ :

A: the variable predicts a crisis and the crisis occurs within four quarters (good "on" signal)

B: the variable predicts a crisis, but no crisis occurs during the signaling period (false crisis signal)

C: the variable does not predict a crisis, but a crisis occurs (missed crisis signal or false calm signal)

D: The variable does not predict a crisis and no crisis occurs (good "off" signal)

These four situations are summarized in the following matrix:

Table 4: Indicator Performance

\begin{tabular}{|c||c|c|}
\hline & IFV* within four quarters $^{*}$ & No IFV within four quarters \\
\hline Signal issued by indicator & A & B \\
\hline No signal issued by indicator & C & D \\
\hline
\end{tabular}

*Increased Financial Vulnerability

We define the following test:

$\left\{\begin{array}{c}H 0: \text { a crisis occurs } \\ \text { against } \\ \text { H1: acrisis does not occur }\end{array}\right.$

or

12 For a more detailed analysis see Andreou, Dufrénot, Sand-Zantman, Zdzienicka (2007). 


$$
\left\{\begin{array}{c}
A \cup C \\
\operatorname{agahst} \\
B \cup D
\end{array}\right.
$$

A type I error of this test is the probability of rejecting $\mathrm{HO}$ when it is true and is defined as $P(C / A \cup C)$. A type II error is the probability of accepting $H O$ when $H 1$ is true, that is $P(B / B \cup D)$. The noise-to-signal ratio is defined as the ratio of type II errors over 1 minus type I errors:

$$
\alpha=\frac{P(D / D \cup D)}{1-P(C / A \cup C)}=\frac{P(B / D \cup D)}{P(A / A \cup C)}
$$

The noise-to-signal ratio is thus the ratio of false signals to good signals. A macroeconomic variable is considered as a good warning indicator of a currency crisis if this ratio has values near 0 . Accordingly, the threshold $\bar{X}$ to be selected must minimize the above ratio. To do this, we use the quantiles of the variable $\mathrm{X}$ and retain those yielding the lowest value of $\alpha$. 


\section{APPENDIX B}

\section{Variables description}

- Commercial Balance /GDP - the ratio of the twelve-month change of exports and imports to nominal GDP.

- Current Account /GDP - the ratio of the twelve-month change of the current account balance to nominal GDP.

- External Debt/GDP - the ratio of external debt at the end of a period over the nominal GDP, twelve-month variation.

- Equity / Debt Ratio - the ratio of equity to debt, twelve-month variation.

- FDI/GDP - the ratio of foreign domestic investment to nominal GDP, twelve-month variation.

- Short-Term Capital Inflows - the ratio of the twelve-month change in portfolio investments to nominal GDP.

- Domestic Credit /GDP - the ratio of the twelve-month change in domestic credit to nominal GDP.

- Banking Credit to the Private Sector - the ratio of domestic bank claims on the private sector as a share of nominal GDP, twelve-month variation.

- Foreign Liabilities in the Banking Sector - foreign liabilities of domestic banks, twelvemonth variation.

- Commercial Banks Deposits - the sum of commercial banks' demand deposits and other deposits, twelve-month variation.

- Real Exchange Rate Appreciation - the real effective exchange rate, twelve-month variation (base year: 1996) - increase means appreciation.

- Exchange Rate Deviation from Linear Trend - deviation of the real exchange rate from its linear trend (base year: 1996). 
- Exchange Rate Volatility - measured as the square root of the monthly exchange rate average and its standard deviation.

- Growth - the twelve-month change in nominal GDP.

- Financial Liberalization - measured by the decrease in the spread between lending and deposit rates.

- Financial Account Volatility - the standard deviation of net annual capital inflows.

- Inflation - twelve-month variation of the consumer price index.

- Interest Rate volatility - the standard deviation of period-by-period change in the money market rate.

- M2/GDP - the ratio of the twelve-month change of M2 to nominal GDP.

- Emerging Markets Financial Situation - calculated on the basis of the monthly EMBI.

- Russian Crisis - dummy indictor of increased financial vulnerability in Russia, constructed as our IFV indicator in formulae (1) to (3). 


\section{APPENDIX C}

\section{Exchange Rate Regimes in the CEECs}

Table 5: Exchange Rate Regimes in the CEECs'

\begin{tabular}{|c|c|}
\hline Bulgaria & $\begin{array}{l}\text { Managed Floating since Feb } 1991 \\
\text { Currency Board peg to euro (DM) since Jul } 1997\end{array}$ \\
\hline Czech Republic & Managed Floating since May 1997 \\
\hline Estonia & $\begin{array}{l}\text { Currency Board peg to euro (DM) since Jan } 1996 \\
\text { ERM } 2 \text { since June 2004 }\end{array}$ \\
\hline Hungary & $\begin{array}{l}\text { Fixed Exchange Rate to the Basket of currencies since Dec } 1991 \\
\text { Crowling peg/band to basket (+/- } 2.25 \% \text { bands) since Mar } 1995 \\
\text { to euro since Jan } 2000,+/-15 \% \text { bands since May } 2001 \\
\text { Floating since the end of } 2003\end{array}$ \\
\hline Latvia & $\begin{array}{c}\text { Fixed Exchange Rate peg to SDR since } 1994(+/-1 \%) \\
\text { peg to euro since Jan 2005, ERM } 2 \text { since May } 2005\end{array}$ \\
\hline Lithuania & $\begin{array}{l}\text { Currency Board peg to USD since Apr } 1994 \\
\text { peg to euro since Feb 2002, ERM } 2 \text { since Jun } 2004\end{array}$ \\
\hline Poland & $\begin{array}{l}\text { Fixed Exchange Rate peg to basket since May } 1991 \\
\text { Crowling peg/band to basket since Oct } 1991 \\
\text { Bands widened since Mar } 1995(+/-2.0 \%) \text { to Mar } 1999(+/-15 \%) \\
\text { Free Floating since Apr } 2000\end{array}$ \\
\hline Romania & "Managed" Floating since Aug 1992 \\
\hline Slovakia & $\begin{array}{c}\text { Fixed Exchange Rate peg to basket since Jan } 1991 \\
\text { Bands widened since Jan } 1996(+/-3 \%) \text { to since Jan } 1997(+/-7 \%) \\
\text { Managed Floating since Oct 1998, ERM } 2 \text { since Nov } 2005 \\
\text { Euro adoption Jan } 2009\end{array}$ \\
\hline Slovenia & $\begin{array}{c}\text { Managed Floating since Oct } 1991 \\
\text { ERM } 2 \text { since Jun 2004, Euro adoption Jan } 2007\end{array}$ \\
\hline
\end{tabular}

Source: IMF, National Central Banks 